\title{
USE OF CONTROLLING IN TOURISM SPHERE AS A MODERN EFFICIENT MANAGEMENT TOOL
}

\author{
Róbert Štefko ${ }^{1}$ \\ Peter Gallo ${ }^{2}$ \\ Daniela Matušíková ${ }^{3}$ \\ Tomáš Molčák ${ }^{4}$
}

DOI: https://doi.org/10.31410/tmt.2019.509

\begin{abstract}
Controlling has been an effective tool for business progress in recent years. Even in tourism sphere there is a need to monitor and evaluate the activities of the subordinates in the companies. The paper deals with the use and application of controlling in tourism facilities. On the theoretical-methodological basis, it clarifies the philosophy of controlling, its goals and tasks. It describes controlling tools and possibilities of their effective use in conditions of tourism. Based on the research conducted in selected tourism companies summarizes the knowledge gained by research and points out the possibilities of applying controlling in the practice of companies operating in the field of tourism. The results of the research are recommendations to companies operating in tourism for the implementation of controlling tools into the company activities and their effective use. The research has confirmed that controlling is an essential tool for effective business management and must be implemented in larger hotel facilities than the department itself, or to be as independent position of the controller. For smaller facilities in this sector, the use of consulting firms in the area of controlling seems to be an effective solution.
\end{abstract}

Keywords: Controlling, Management, Tourism, Management Tools, Hotel Controlling.

\section{INTRODUCTION}

$\mathrm{T}$

oday, the business environment in the tourism industry is a very dynamically evolving system. It is therefore important for every company to be competitive and successful. Organizations in the sector must strive to innovate constantly and follow new trends, steps and processes to improve their management systems. Their main goal is to ensure competitiveness, liquidity, profitability and optimal capital structure so that the value of the company gradually grows. In connection with the modernization of the management of tourism businesses, it is therefore necessary to introduce modern management methods such as controlling. The aim of the paper is to analyse the situation related to the use of controlling in these facilities and to propose procedures for its more effective application based on research in tourism companies.

In this case, the question may appear: Why controlling? Controlling precisely because today it can be classified as a modern management method significantly supported by information and communication technologies. In Slovakia, but also in other European countries, the digital transformation of the economy is taking place, and this transformation also affects the area of tourism development and increasing its competitiveness. It is all the more urgent nowadays, when a major global pandemic occurred in the first months of 2020, and solutions are being sought to restore the tourism that has essentially stopped in this period and is experiencing huge losses.

\footnotetext{
1 Faculty of Management, University of Prešov in Prešov, Konštantínova 16, 08001 Prešov, Slovakia

2 Faculty of Management, University of Prešov in Prešov, Konštantínova 16, 08001 Prešov, Slovakia

3 Faculty of Management, University of Prešov in Prešov, Konštantínova 16, 08001 Prešov, Slovakia

4 Faculty of Management, University of Prešov in Prešov, Konštantínova 16, 08001 Prešov, Slovakia
} 
Many companies are looking for help from the state, which can be judged right, but not effective without a good management method. The companies with quality controlling systems can respond to changed market requirements and transform the economy and hotel management into crisis management, where controlling will show them the right way.

Based on the experience that we have with its implementation in the industry and tourism sectors, this is where we see the weakness of these facilities/companies. The tourism facilities in Slovakia should quickly complete the controlling systems and implement them in their operation. By its existence, they can control all the processes and effectively influence their management. Operational interventions such as cost cuts will not be effective in this case, although sometimes such measures need to be taken. The state should help in solving operational problems, but from the perspective of the future, controlling is an effective tool. This led us to a deeper knowledge and research of this issue in the field of tourism development in Slovakia.

\section{THEORETICAL AND METHODOLOGICAL BACKGROUND OF CON- TROLLING AS A MODERN MANAGEMENT TOOL}

The basic definitions of controlling are based on the view that controlling is basically processing relevant and reliable information by adequate methods into reports in support of managerial decision-making and business management.

According to Vidová (2009) controlling is a subsystem in the management system that coordinates planning, organizing and controlling processes and based on their analysis, provides management with the information necessary for decision-making.

Controlling presents an element of business management through which errors, deficiencies can be identified by comparing the plan and reality.

Another definition up to Vollmuth $(2001,2004)$ define controlling as a management tool that goes beyond the functional framework of current management and supports management and decision-makers. Such management is envisaged under conditions where the enterprise has developed a planning methodology based on the objectives set by the management and its managers. Deviations from individual responsible areas of the company are detected by the comparative method.

Other author Baran (2008) states that controlling is a set of rules that helps to achieve business goals, avoids surprises, and if there is a danger that requires effective management measures to eliminate it, it will „turn red" in time. It is a subsystem of a management system that is functionally cross-cutting in nature and as a management tool it supports business decision-making and management processes - Scheme 1 .

We consider controlling as an important tool of business management in tourism, which is used to analyse the internal processes and the external environment of the company, to uncover reserves, measure future effects and measures to achieve the target with the lowest material, labour and financial costs strategic goals of business development (Sládek, Valentová 2006). Hedija and Fiala (2019) state that these management methods should be used both in small and large enterprises- but the scope of use of these systems should always be considered. 
More authors agree that the basis of the term controlling is the term ,control' or „to control”, which can be understood in two different meanings:

- the meaning of management, control, holding under control,

- the meaning of control and verification (in English this can be expressed by the verb "to check") (Eschenbach, Siller 2012).

Gallo (2006) mentions that controlling is a tool for managing a business to its success. Through the consistent use of controlling tools, the company is able not only to conduct its goals, but also to effectively plan the future, find deviations and propose solutions to achieve the set goals and fulfil the vision.

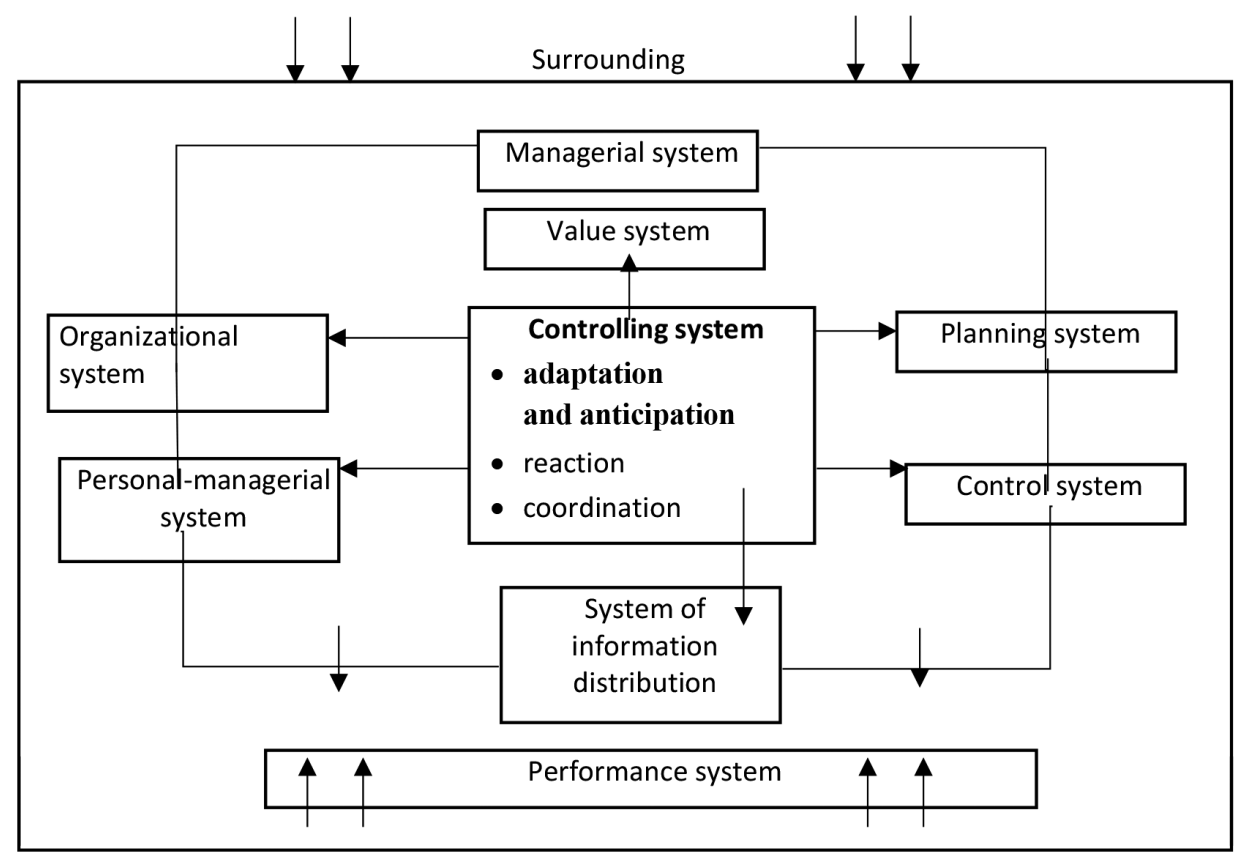

Scheme 1. Controlling in a system of company management

Source: Baran, 2008

As the main objective of controlling as other author Eschenbach (2004) mentions, is to maintain the competitiveness and viability. This goal can be achieved with the support of top management, which through controlling has capabilities such as ensuring the ability of anticipation and adaptation, ensuring the ability to respond and ensuring the ability of coordination.

Fibírová (2003) adds that these immediate goals are followed by mediated goals, namely the goals, wishes and requirements of the stakeholder groups. These groups are mainly investors, employees and customers, competitors, suppliers and the like.

However, controlling already fulfils new functions in relation to modern management theories based on business performance. These include the Balanced Scorecard, SixSigma and EFQM quality models. These enforce more modern management directions based on KPIs' key performance indicators. It is also appropriate to use benchmarking tools such as Creditworthy Model, point out Onferová and Čabinová (2018). 


\subsection{Controlling in terms of its functions}

Several authors as Eschenbach et al. $(2004,2012)$ state that controlling functions include management functions that include maintaining and developing the business and economic system and tools, system coordination and management, actively contributing to the development and recovery of a business by bringing the controlling ownership of thought into business decisions. Coordination of the whole management system is an essential task of management controlling.

The authors mentioning the topic of controlling describe the definition and functions of controlling differently. Some of them mention reporting and information functions as a separate category. This is also mentioned by another researcher of this field Fibírová (2003). She describes the planning, information and reporting functions. According to her, reporting structures the information into a form that suits the target user, after the information function is based only on acquisition, documentation and control.

Vravec (2012) mentions basic functions of controlling that include description of business processes and activities, creation and implementation of regulations, directives and standards, as well as the actual implementation of controlling activities of the company.

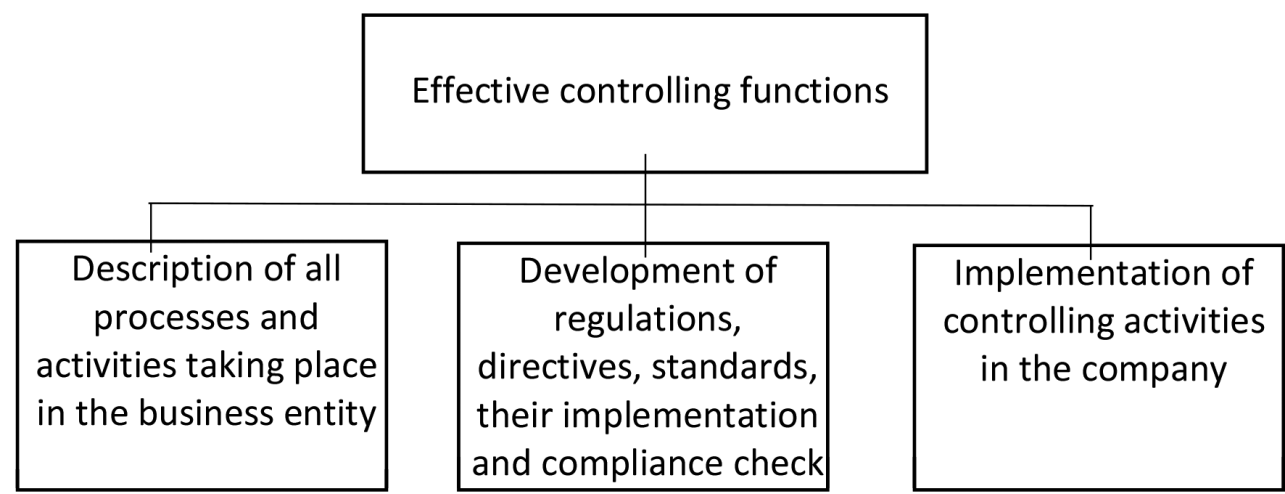

Scheme 2. Functions of effective controlling

Source: Vravec, 2012

The role of controlling is to sort individual components, check their usability, supplement them and move them further into the management system (Mann 1992).

\section{CONTROLLING IN TOURISM ENTERPRISES}

Information and knowledge are becoming a decisive aspect of success in the modern knowledge-based economy and often represent a decisive competitive advantage. Controlling should therefore represent a modern method of business management based on accurate information that serves to increase the market value of the business, high profitability, liquidity and risk reduction (Širá e al. 2018, Vravec, 2012).

Based on the experience with the implementation of controlling in business practice, several points have been selected that characterize controlling and by means of which the company can be put on the path to successful management. These points form, on the one hand, the centre of controlling management and, on the other hand, it is the basis to which other special controlling methods and approaches that are not applicable without these points are attached. 
- An enterprise must introduce a further cost breakdown into its economic management practice,

- The company must regularly calculate the short-term profit or loss,

- The company must switch to the calculation of the coverage allowance and the production critical point,

- The company must create a profit centre system (Gallo 2013, Gallo 2015, Konečný 2007).

When introducing controlling into the company, it is necessary to distinguish the difference between the controlling function and the controlling institution (Vravec 2012, Gallo 2006, 2013, 2015).

\subsection{Time dimension of controlling and its tools}

According to Folínová et al 2007 and Foltínová, Kalafutová (1998), controlling focuses on the present as well as the future. It takes information and data from the past that help the company to manage and progress. In terms of time, business planning consists of two basic types, namely strategic and operational planning. In strategic controlling, we are talking about long-term corporate governance, while operative controlling focuses on short-term management.

Gurčík (2004) also introduced that the less known tactical form of business management. "Operational controlling aims to "do the thing in a right way", while strategic controlling aims to "do the right thing" (Synek 2003, Synek 1996).

Strategic controlling focuses on the future, which means regular and systematic monitoring of future threats and opportunities. It reveals future chances and risks based on the forecast of external and internal changes, recognizes deviations from the set objectives before interfering with operational plans. According to Eschenbach (2012) strategic and Operational Controls Interact to each other.

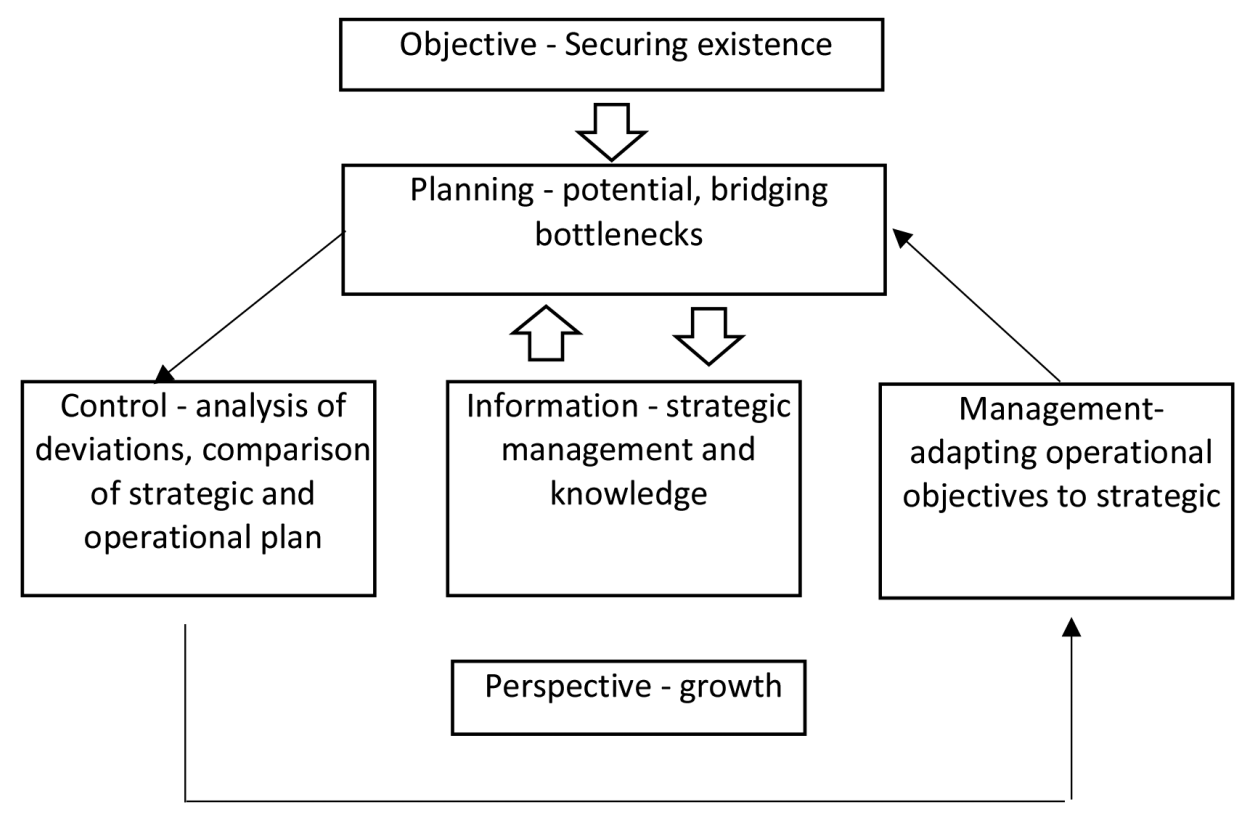

Scheme 3. Strategic controlling

Source: Foltínová, Kalafutová 1998 
Dvoráček (2005) points out concrete qualitative tools include SWOT analysis, PEST analysis, BCG matrix and Porter model, brainstorming, dolphin method, six thinking hats method, cost-benefit analysis and others.

"The division of instruments respectively methods of strategic controlling to basic and special. The basic methods are divided into methods of strategic controlling in the company and its surroundings“ (Bogyová 2011).

The methods of strategic controlling in the company include: SWOT analysis, business logistics, experience criticism, value analysis, potential analysis, business life cycle curve, own production and subcontracting, comprehensive quality management and target cost management.

The methods of strategic controlling of the company's surrounding include: Portfolio analysis, competition analysis, strategic gap and scenario techniques.

Special methods: Early warning system, strategic balance sheet, long-term business success, extended portfolio matrix and strategic polar diagram.

Operational controlling is represented mostly at lower levels of management and its activities help to short-term decisions of the company. The rule is a one-year horizon. By interfering with business processes (especially tactical and operational planning and budgeting), it ensures efficiency in terms of economy and profitability, helping to achieve strategic goals, concludes Mikovcová (2007).

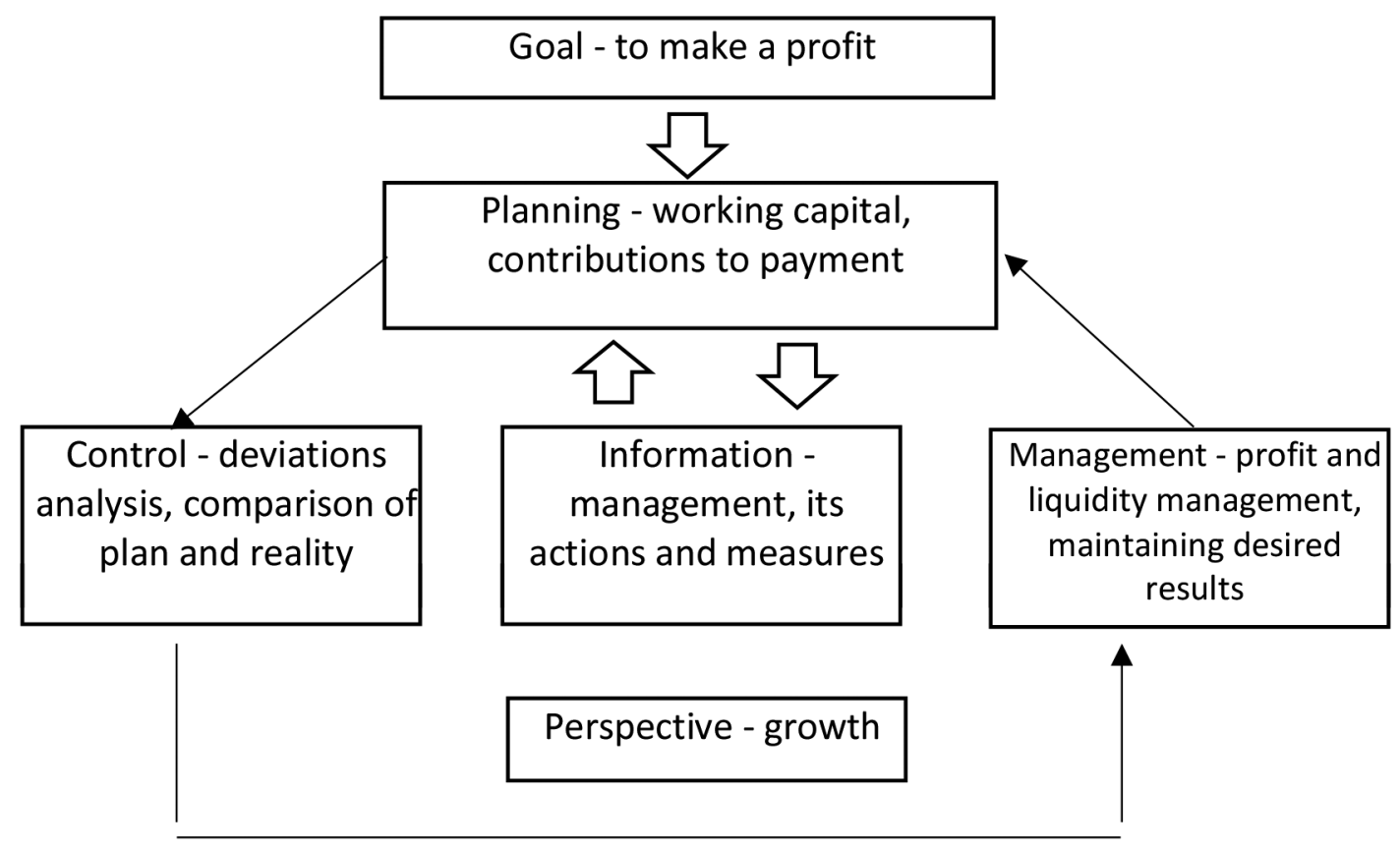

Scheme 4. Operative controlling

Source: Foltínová, Kalafutová 1998

Operational controlling is considered primarily as the basis of short-term profit management in the company. It strives to balance sales, costs and profits on the one hand with the financial stability of the business on the other (Konečný 2007). 
Operational tools are divided into basic, special and other:

- Basic tools of operational controlling - break - even point analysis, calculation of contribution for reimbursement, calculation of short - term economic result, analysis of bottlenecks;

- Other methods of operational controlling - ABC analysis, XYZ analysis, order volume analysis, order volume optimization, production batch size optimization. These tools are focused on the management of current assets. Business management tools include "analysis of rebates, sales areas and commissions";

- Special tools of operational controlling - quality circles, performance plans, planned balances, liquidity plan and investment budgets (Vollmuth 2001,2004).

\subsection{Hotel controlling}

"Hotel controlling uses all general controlling tools. These are in the area of financial, cost and strategic controlling, as well as controlling of the other industries. It must take into account in part the system of links (Šenková 2018, Tej, Ali Taha 2017), which exists in the accommodation and catering establishment, its organizational structure, its cost structure, seasonal fluctuations and so on.

In accommodation facilities and service facilities, the role of controlling is great and multiplied, in particular by the fact that any causes that do not realize planned sales and output leave a situation that cannot be changed in any given period. In hotel services, the decisive factor of sales and performance is the time of implementation. If sales are not realized in a given period, they remain permanently irreplaceable. It is not possible to replace unsold accommodations or to catch up in the future. They are a loss with consequences for the economic results of the hotel" (Gallo 2015).

"For the managers of accommodation facilities or hospitality, controlling is an extremely effective management tool. Controlling organized and implemented based on up-to-date and verified data significantly streamlines management activities. Instead of controlling by often problematic one-off and poorly proven procedures and intuition, controlling uses exact methods and procedures that limit or eliminate the possibility of inaccurate conclusions and inconsistent measures in assessing the economic condition of a business in meeting the marketing strategy goals" (Sládek, Valentová 2006, Gurčík 2004).

According to several authors (Sládek, Valentová 2006, Steinocker 1992, Goothilf 2002) hotel controlling activities rank among the basic ones:

- Supply Controlling,

- Accommodation prices controlling,

- Food and beverage prices controlling,

- Cost controlling,

- Revenue controlling.

By developing the science of controlling it is possible to specify and effectively use new types of controlling. Modern types of controlling include (Horváth 2004, Gallo 2013, Freiberg 2006):

- Personal controlling,

- Marketing controlling,

- Sales controlling, 
- Process controlling,

- Controlling business performance.

\section{ANALYSIS OF THE CONTROLLING USE IN SELECTED HOTEL FACILITIES- METHODOLOGY}

The main objective of the research was to analyse the use of controlling and its tools in selected accommodation facilities in hotel facilities. Subsequently, make recommendations for tourism businesses to use the controlling tools effectively in this sector. The research was carried out by a questionnaire survey, which was designed to point out the importance and benefits of controlling.

As part of our research, we were trying to find the answer to the following problem questions:

- Is the use of tools suitable for tourism facilities?

- Which type of equipment and how much can it use controlling tools in management?

- Who should perform controlling functions in tourism facilities?

- What is the benefit of controlling for the effective management of tourism organizations?

Based on the identified problems, we have formulated the following hypotheses to confirm or reject our assumptions.

- Hypothesis H1: We assume that all accommodation facilities assess the financial situation similarly.

- Hypothesis H2: We assume that the establishment of a separate controlling section in hotel facilities is comparable.

- Hypothesis H3: We assume that there are no differences in the representation of departments acting as controllers in hotel facilities.

- Hypothesis H4: We assume that accommodation facilities consider controlling as an equally necessary and effective tool of business management.

Characteristics of the survey sample. The survey sample was chosen within selected tourism facilities/companies operating in Slovakia. In concrete, these were hotels, guesthouses, hostels and others. Distribution of questionnaires among respondents in selected facilities/companies was made electronically. A total of 350 tourism facilities/companies were addressed. The rate of return was 175 questionnaires. Of total 175 facilities/companies- 34.3\% were hotels, $54.3 \%$ guesthouses and $11.4 \%$ other facilities were mostly hostels.

Research methods. The research and analysis of the current situation was based on a questionnaire with 13 structured questions. The introductory questions focused on general information about the addressed facility. Others were focused on information about the financial situation of the facility, the use of company controlling and the functions of controlling, its benefits for the company and costs.

Overview and analysis of results. We used frequency analysis and graphs to interpret the results. The results of the questionnaire survey were processed into graphs, in which we recorded the values as a percentage and then we also described the individual graphs and verbally evaluated. The research objects were hotels, guesthouses and hostels - graph 1. 


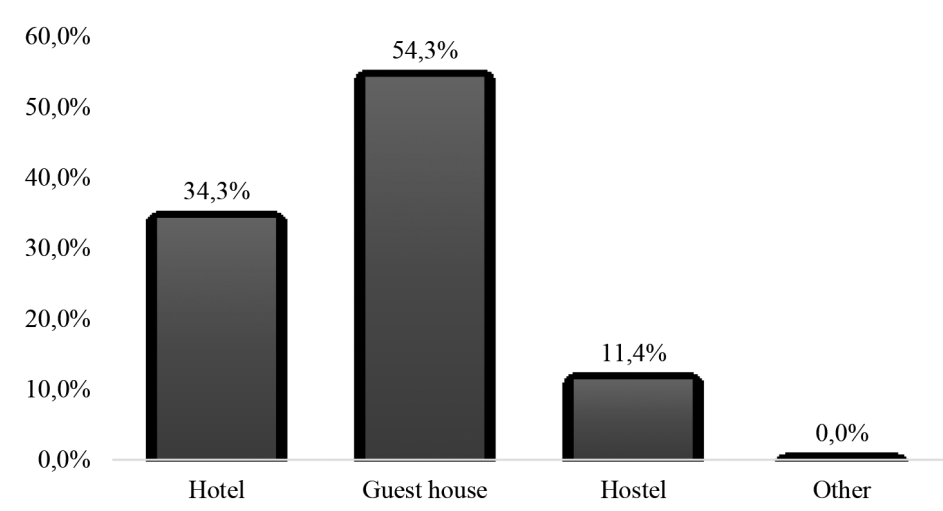

Graph 1. Type of accommodation establishment

Source: own processing

As shown in the above chart, $54.3 \%$ were guesthouses, $34.3 \%$ were hotels and $14 \%$ of establishments were hostels. We used this data to evaluate most of our research questions because we will look at the frequency of responses in terms of accommodation establishment type.

We received the answers (shown in Graph 2) to the questionnaire question on how the accommodation establishments evaluate their financial situation.

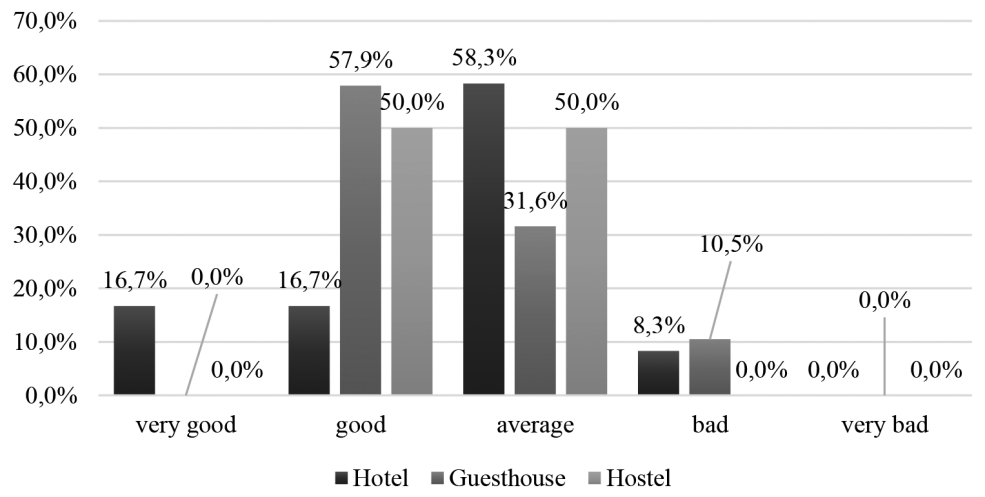

Graph 2. Evaluation of own financial situation

Source: own processing

Option very good financial situation chose $5.7 \%$ of the surveyed facilities among all surveyed facilities and $16.7 \%$ of hotels. $16.7 \%$ of hotels, $57.9 \%$ of guesthouses and $50 \%$ of hostels commented on the good financial situation. The fact that the financial situation in the facility is at an average level in the survey was acknowledged by $58.3 \%$ of hotels among surveyed hotels, $31.6 \%$ of guesthouses and $50 \%$ of hostels. $8.3 \%$ of hotels and $10.5 \%$ of hostels rate their poor financial situation. None of the surveyed accommodation responded to the survey option that they were financially very bad, and would consider closing the facility.

Furthermore, we examined when selected establishments invested to the modernization of facilities in their buildings. The results can be seen in the Graph 3.

According to the survey results among the surveyed accommodation facilities, $57 \%$ stated that they had upgraded their facilities in the last 2 years. The answer to the question concerning the establishment of a separate controlling section was as follows - Graph 4. 


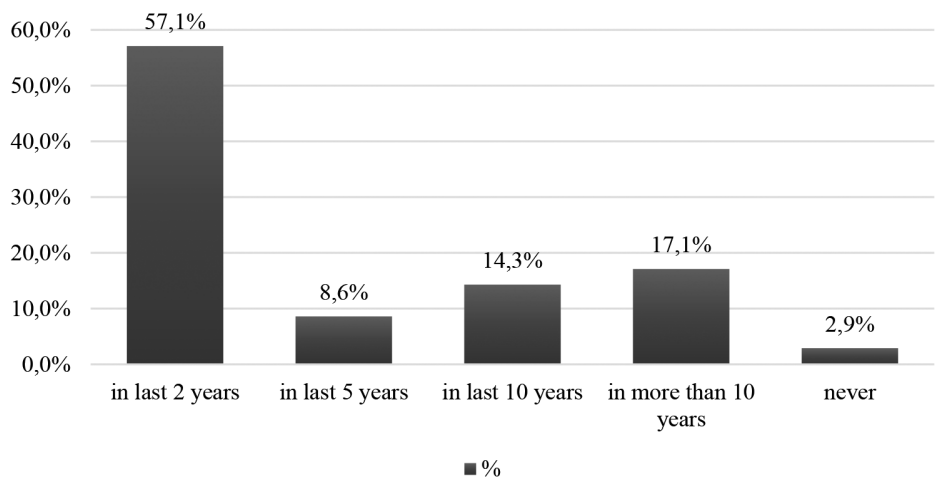

Graph 3. Modernization of establishments

Source: own processing

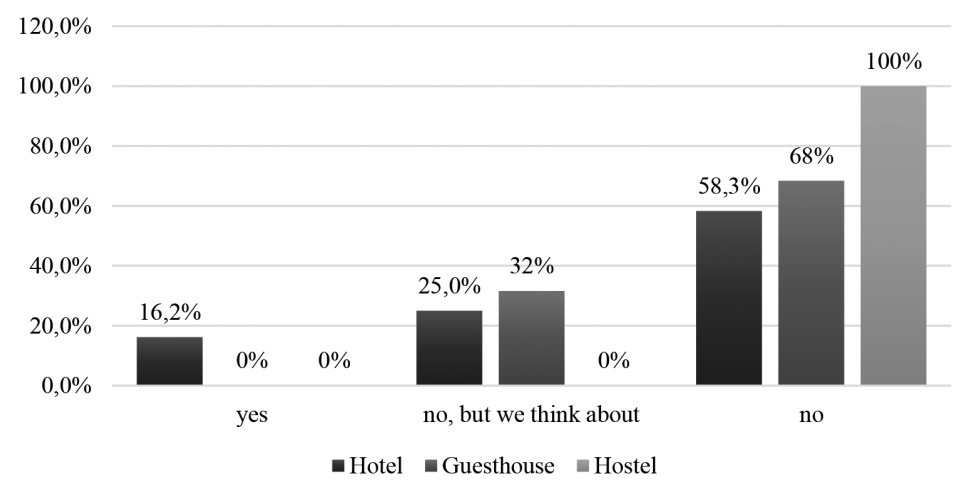

Graph 4. Independent controlling section

Source: own processing

From the answers to the question about controlling, we found that more than half of the surveyed facilities, in concrete $68.6 \%$ do not have a separate controlling section, while $25 \%$ of surveyed hotels and $31.6 \%$ of guesthouses are considered to be set up.

In the next question, we focused on finding out who is responsible for the controlling in accommodation facilities. The responses are shown in Graph 5.

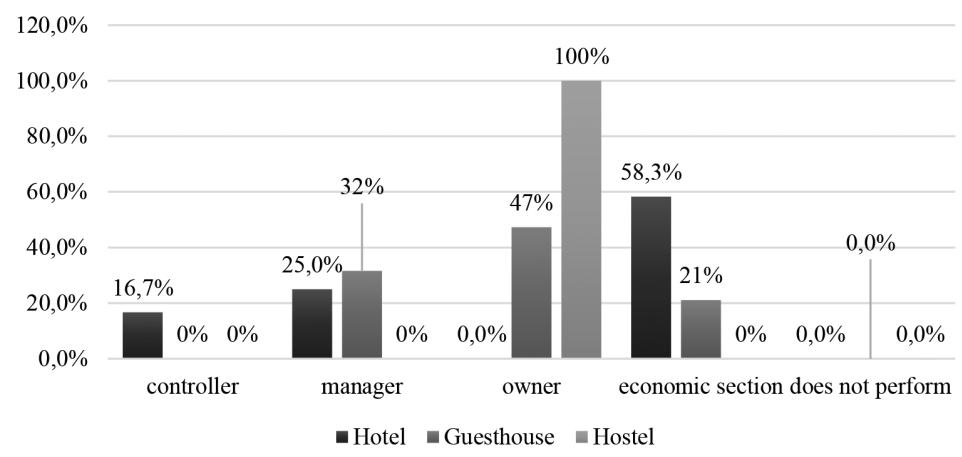

Graph 5. Responsible person for controlling management in the company

Source: own processing

As the above chart shows, most of the surveyed facilities do the controlling activities by their owner. The second in terms of abundance was the response that controlling is performed by the economic department in the company, which was stated in the survey by $58.3 \%$ of surveyed 
hotels and $21.1 \%$ of surveyed guesthouses. $25 \%$ of hotels and $31.6 \%$ of guesthouses stated that the manager performs controlling in the facility. Controller as a person performing controlling in accommodation facilities stated $16.7 \%$ of interviewed facilities.

When asked what area is controlling focused on, which they perform in their facilities. The answers can be seen in the Graph 6.

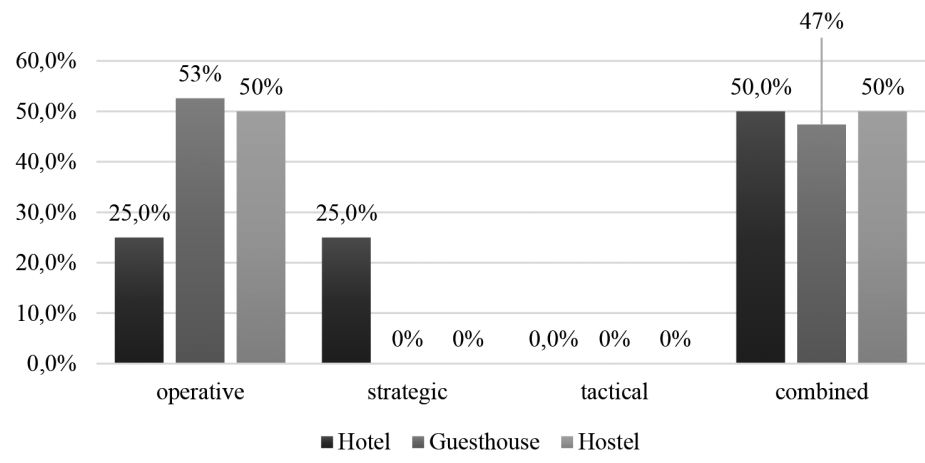

Graph 6. Controlling focus

Source: own processing

The responses show that the operational and combined focus of controlling prevails.

We answered the question of the importance of controlling in cost management as shown in Figure 7.

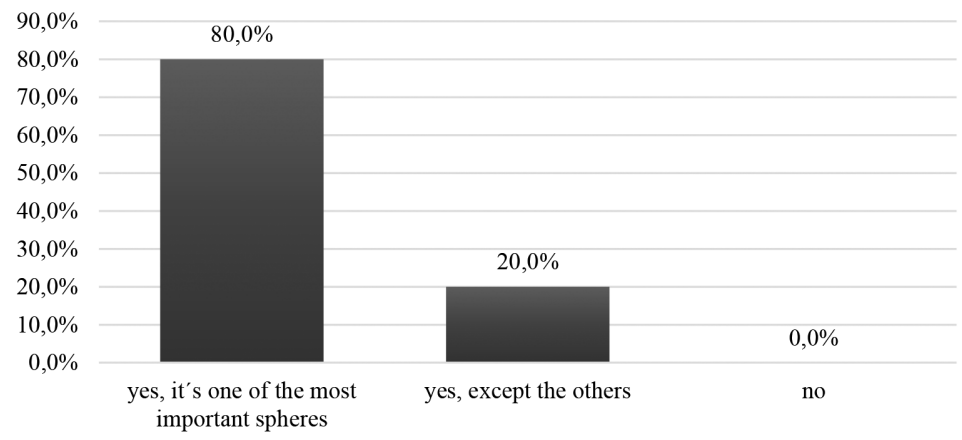

Graph 7. The importance of controlling in cost management

Source: own processing

As we can see, $80 \%$ of establishments think that controlling is an important tool in cost management.

When we asked what purpose of controlling tools in the surveyed facilities is fulfilled, we have received the following answers - Graph 8.

According to the survey results, controlling is the most widely used for evaluating financial indicators according to the surveyed facilities $(60 \%$, of which $66.7 \%$ for hotels, $63.2 \%$ for guesthouses and $25 \%$ for hostels).

When asked whether the owners, respectively management of surveyed facilities, whether they consider controlling as an effective tool of company management, we obtained the following answers - Graph 9. 


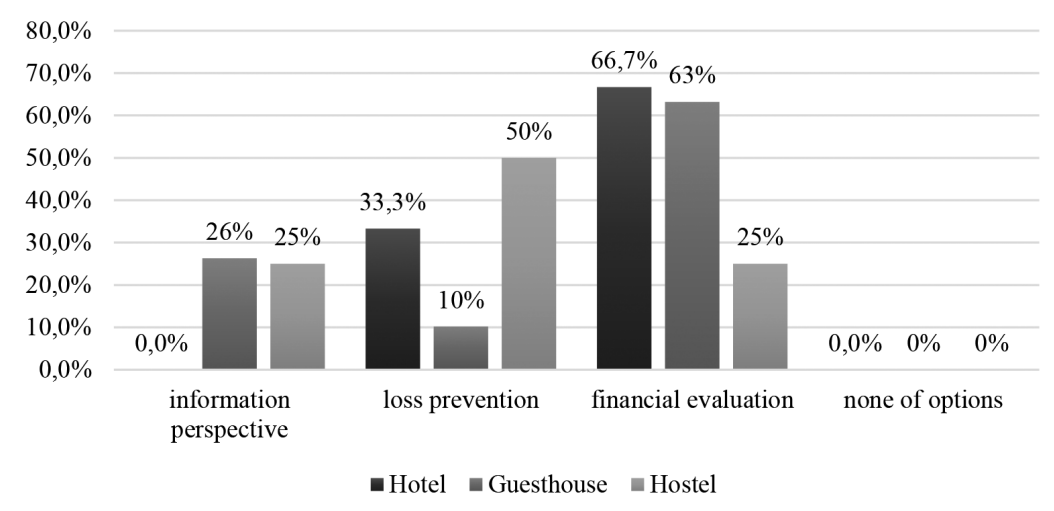

Graph 8. Purpose of controlling tools

Source: own processing

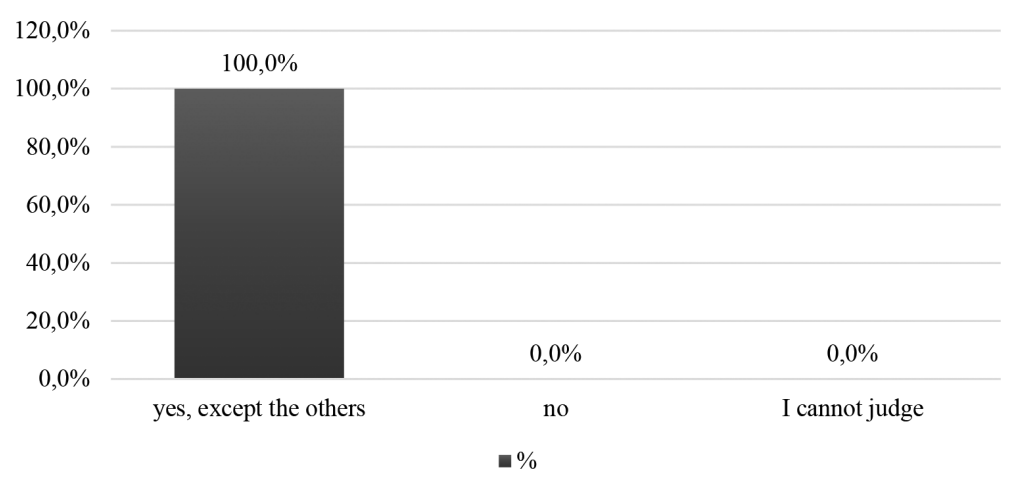

Graph 9. Controlling as an effective business management tool

Source: own processing

As can be seen from the responses shown in Graph 9, it is clear that all the establishments involved in the survey are of the opinion that controlling is an important and especially effective tool for managing their hotels, guesthouses and hostels.

\section{Statistic hypothesis testing}

We have formulated the problem areas of our research into four hypotheses. Each hypothesis was followed by an alternative hypothesis.

\section{Hypothesis H1:}

- H1 zero: We assume that accommodation facilities evaluate the financial importance in a comparable way.

- H1 alternative: We assume that accommodation evaluates facilities evaluate financial importance differently.

To verify the hypothesis, we used the Kruskal-Wallis test with correction for the order of the matches. We set the significance level of $5 \%$ on both sides. The Kruskal-Wallis test is a non-parametric analysis of variance. We decided not to test the agreement of specific parameters, but to match the selection distribution functions of the compared files, with the key assumption being the independence of the observed values. For similar reasons we decided to use the F-test. The objective of the F-test for equality of two variance was to verify that two sample sets came from a distribution with the same variance, which means to verify that both sets showed approximately the same variance of the random variable of interest. Table 1 shows the results of hypothesis 1 testing. 
Table 1. Frequency overview of financial situation assessment achieved results

\begin{tabular}{|c|c|c|c|}
\hline Financial situation & Hotels & Guest houses & Hostels \\
\hline Very good & $17 \%$ & $11 \%$ & $0 \%$ \\
\hline Good & $17 \%$ & $11 \%$ & $50 \%$ \\
\hline Average & $58 \%$ & $37 \%$ & $50 \%$ \\
\hline Bad & $8 \%$ & $5 \%$ & $0 \%$ \\
\hline Very bad & $0 \%$ & $0 \%$ & $0 \%$ \\
\hline
\end{tabular}

Source: own processing

Table 2. Results of Kuskal-Wallis test

\begin{tabular}{|c|c|c|}
\hline Test & & \\
\hline i4 & 34,5 & \\
\hline i3 & 26 & \\
\hline i2 & 11 & \\
\hline i1 & 2 & T3 \\
\hline T1 & T2 & 74 \\
\hline 200 & 356 & \\
\hline
\end{tabular}

Source: own processing

Results: $\mathrm{H}=0,311, \mathrm{H}$ adjusted $=0,369, \mathrm{H}$ critical $=5,796, \mathrm{p}=>0.05-$ test is not important.

Result: The null hypothesis is not rejected. The financial situation is comparable.

Based on the test carried out and the findings of the survey, it was confirmed that the accommodation facilities had indicated their financial situation comparably. There are no significant differences between different types of accommodation facilities. The most frequent responses were good and average when assessing the financial situation. When evaluating hypothesis 1 we used data from questionnaire question number 5.

\section{Hypothesis H2:}

- H2 zero: We assume that the establishment of a separate controlling section is comparable.

- H2 alternative: We assume that the establishment of a separate controlling section is not comparable.

We used the extended Fisher association test to test the hypotheses. The significance level is 5\% on both sides. The test results are shown in Table 3.

Table 3. Overview of the frequency of achieved results of the establishment of the controlling section

\begin{tabular}{|c|c|c|c|}
\hline \% & Hotels & Guesthouses & Hostels \\
\hline Very good & $17 \%$ & $0 \%$ & $0 \%$ \\
\hline Good & $25 \%$ & $32 \%$ & $0 \%$ \\
\hline Average & $58 \%$ & $68 \%$ & $100 \%$ \\
\hline
\end{tabular}

Source: own processing

$\mathbf{p}=0,303-$ test is not significant $(\mathrm{p}>0,05)$.

Result: The null hypothesis is not rejected. The establishment of a separate controlling section is comparable. 
By testing another hypothesis, which follows from questionnaire question no. 9, we found that the establishment of a separate section of controlling is comparable in all types of accommodation facilities. According to a questionnaire survey, most of the respondents do not have implemented such a section in their facility.

\section{Hypothesis no. 3:}

- H3 zero: We assume that on behalf of units that play a function of controller, there are no differences.

- H3 alternative: We assume that on behalf of units that play a function of controller, there are differences.

For the hypothesis testing, we used the extended Fisher's test of association. The significance level is $5 \%$ on both sides. An overview of the test results is given in Table 4.

Table 4 Overview of the number of results achieved by the controlling section

\begin{tabular}{|c|c|c|c|}
\hline $\begin{array}{c}\text { Controller function } \\
\text { section }\end{array}$ & Hotels & Guesthouses & Hostels \\
\hline Owner & $0 \%$ & $47 \%$ & $100 \%$ \\
\hline Economic section & $58 \%$ & $21 \%$ & $0 \%$ \\
\hline Manager & $25 \%$ & $32 \%$ & $0 \%$ \\
\hline Controller & $17 \%$ & $0 \%$ & $0 \%$ \\
\hline Does not work & $0 \%$ & $0 \%$ & $0 \%$ \\
\hline
\end{tabular}

Source: own processing

$\mathbf{p}=0,001-$ test is significant $(\mathrm{p}=0.001<0.05)$

Result: We accept the alternative hypothesis. There are significant differences in the division of units that fulfil the function of the controller.

After performing the test of the third hypothesis, for which we obtained data after the evaluation of the 10th questionnaire question, we found that when comparing individual types of accommodation facilities there are significant differences in hotels, guesthouses and hostels. We attribute this difference to the fact that the owner performs this function in the hostels. Only hotels were mentioning a separate position of the controller. Since the hotel has other sections than just accommodation and catering and also has a greater capacity, at a higher level it is necessary to have a separate position of controller in such facilities.

\section{Hypothesis no. 4}

- H4 zero: We assume that there are no differences between the fulfilling purposes of the controlling tools of the accommodation facilities.

- H4 Alternative: We assume that there are significant differences between the fulfilling purposes of the controlling tools of the accommodation facilities.

For the hypothesis testing, we used the extended Fisher's test of association. The significance level is $5 \%$ on both sides. The results of tested hypothesis are shown in Table 6.

$\mathrm{p}=0,069-\quad$ test is not significant $(\mathrm{p}>0.05)$ 
Result: The null hypothesis is not rejected. There are no differences between the facilities in the fulfilling purposes of controlling tools.

Table 6 Frequency overview of achieved results of the purpose of using controlling tools

\begin{tabular}{|c|c|c|c|}
\hline Purpose & Hotels & Guesthouses & Hostels \\
\hline Information aspect & $0 \%$ & $26 \%$ & $25 \%$ \\
\hline Losses Prevention & $33 \%$ & $11 \%$ & $50 \%$ \\
\hline Financial valuation & $67 \%$ & $63 \%$ & $25 \%$ \\
\hline None & $0 \%$ & $0 \%$ & $0 \%$ \\
\hline
\end{tabular}

Source: own processing

In the last hypothesis, we focused on the fulfilling purpose of controlling in the accommodation facility. For the hypothesis, we used data from the 13th questionnaire question.

The highest frequency of responses was recorded for the financial evaluation purpose of the facility. From the test, we found that there are no significant differences in the use of controlling tools between different types of accommodation facilities.

\section{SUMMARY OF ACHIEVED RESEARCH RESULTS AND DISCUSSION}

Based on the survey conducted in tourist accommodation establishments and testing of established hypotheses, we can conclude that the term "controlling" is known to the surveyed facilities.

From a financial perspective, a key group of questions was the assessment of own financial situation. We can say that companies evaluate their financial situation as good and average. This is mainly attributed to the fact that most facilities have been upgraded in the last 2 years and expect a return from 1 to 5 years. This implies that facilities are constantly striving to adapt to market requirements. We later used this knowledge to test the hypothesis, where we tried to find out whether there are significant differences in the assessment of the financial situation between different types of accommodation facilities. The hypothesis that these facilities assess their financial situation comparably has been confirmed. Financial controlling is very helpful in evaluating of this area.

It is based on financial analysis. Before deciding on any investment, we suggest doing a financial plan so that business managers can predict the consequences of their investment decisions. This issue deals with the so-called investment controlling, which may, however, form part of financial controlling and is used for financial planning.

In the long-term perspective, SWOT analysis is an important tool of strategic business management. By using this tool, companies can effectively allocate their funds and thereby contribute to improving the financial situation, but also effectively strategically influence their future success.

An important outcome of the survey was that most of the surveyed establishments do not have a separate controlling section. This was confirmed by the hypothesis concerning the comparison of the types of accommodation and their establishment of the controlling section. The test showed that the establishments were comparable. Only hotels with a larger number of employees have this management system in place, and this is the position of the controller. In other facilities, this function is most often entrusted to the owner, less often the economic department or the manager of the company. 
In case the company does not have and does not even consider a separate section and function of the controller, we propose to acquaint all employees with the issue of controlling. The solution is also companies engaged in consulting on this issue and their training courses. Employees should be familiar with the term, its functions, tasks and usage patterns so that they are able to point out an impending threat in a timely manner, or to effectively address problems encountered in the business in its various sections.

It is clear from our findings that accommodation facilities mainly use a combined form of controlling. Such a form is effective as the company seeks short and long-term management. We also found from the research that most of the facilities are mostly oriented to operational controlling and strategic controlling is either absent or sporadic. We attribute this to the fact that this form of control is applied at higher levels of control that other devices do not have.

The research also shows that the most common facilities in tourism are oriented towards cost controlling and consider it one of the most important in the area of management. The nature of accommodation and catering services implies that predominantly fixed costs, which are important to monitor regularly.

We found out that accommodation facilities use controlling mainly to evaluate financial activities. We did not notice any differences in significance between the different types of facility, which was the result of the last hypothesis.

Overall, it can be concluded that all interviewed entities consider controlling as an effective tool of company management. As showed, controlling with its tools is an important element in the effective management of tourism businesses. Although some facilities do not have the position of a controller, we recommend that they use the services of an external worker - the controller, to streamline their management process and improve their position in a competitive environment. This worker receives information remotely by sending the device the new and necessary information. These workers have significant professional knowledge, not only theoretical but also practical, related to this issue.

\section{CONCLUSION}

In Slovakia and especially in tourism sphere, controlling is not considered an obvious part of company management, which may result in insufficient information and qualification of employees in this area. The aim of the research was to analyse the current state of its use in accommodation facilities in selected tourism facilities. In the case of controlling in tourism, there are major shortcomings in the direction of its use and implementation in companies in this area of business.

At present, especially with the pandemic situation at the end of 2019 in the Asian continent and its subsequent transfer to Europe, there has been a threat to the development of tourism, and many facilities have reached the threshold of existential problems. Majority of them are looking for a way out of this situation. This is even worse because businesses in this sector did not count on such a large slump, especially in EU countries. Short-term measures are on the side of the state, which should help keep tourism running. However, all facilities/companies are unlikely to be able to exist in the future as expected. Who currently has strong controlling and can use, he (company) can much easier and more effectively outperform today. New financial and strategic 
plans need to be drawn up immediately and implemented at the moment. This means that profitability is dropping in the event of a sharp fall in sales, and a simple dismissal does not solve it.

For this reason, they may no longer need only financial controlling and a crisis financial plan, but they must build strategic controlling based on perspectives (financial, customer, process and growth learning). That means already today they must lay the foundations for the future. The philosophy of controlling can help here:

- focus on bottlenecks,

- have perspective thinking,

- look to the future.

What does this practically mean for the tourism industry? Identify bottlenecks immediately and propose operational and strategic solutions to these problems. Think of how the tourism market will evolve and which innovative directions will affect it. How the world will change due to a pandemic for the coming years. Which device doesn't have it can expect big problems. Looking at it through the characteristics of successful companies, the first thing is to be active and not wait. Then it is necessary to have a new quality strategy, a flexible organizational structure and adapt to the new conditions. As a fourth factor of success is having a quality team that can handle it. Therefore, the release of key personalities from businesses in times of crisis can cause irreparable damage.

\section{ACKNOWLEDGEMENT}

Scientific Paper was elaborated within the framework of the project APVV no.17-0166 (Economic and psychological factors of tourist expenditures in tourism: micro-econometric modelling)- (in original version: APVV-17-0166 Ekonomické and psychologické faktory výdavkov turistov v cestovnom ruchu: mikroekonometrické modelovanie) held on Faculty of Management, University of Prešov in Prešov, Slovakia.

\section{REFERENCES}

Baran, D., 2008. Aplikácia controllingu v podnikovej praxi. Bratislava: STU.

Bogyová, E. et al., 2011. Kontroling v malých a stredných podnikoch. Banská Bystrica: UMB.

Dvořáček, J., 2005. Audit podniku a jeho operací. Praha: C. H. Beck,

Eschenbach, R. a kol., 2004. Controlling. Praha: ASPI Publishing, s.r.o.

Eschenbach, R., Siller, H. 2012. Profesionální controlling: koncepce a nástroje. Praha: Wolters Kluwer.

Fibírová, J., 2003. Reporting: moderní metoda hodnocení výkonnosti uvnitř firmy. Praha: Grada Publishing.

Foltínová, A. a kol., 2007. Nákladový controlling. Bratislava: SPRINT.

Foltínová, A., Kalafutova, L., 1998. Vnútropodnikový controlling. Bratislava: Elita.

Freiberg, F., 1996. Finanční controlling. Koncepce finanční stability firmy. Praha: Management Press.

Gallo, P. 2006. Podnikový controlling. Prešov: Dominanta.

Gallo, P. 2013. Strategický manažment $a$ controllingové analýzy. Prešov: Dominanta.

Gallo, P. 2015. Hotelový controlling [online]. [cit. 2015-11-18]. Dostupné z: http://www.dominanta.sk/HotelContr.htm.

Goothilf, D, L., 2002. Treaurer's and Controller's Desk Book. New York: Amacom. 
Gurčík, L., 2004. Podnikatel'ská analýza a kontroling. Nitra: SPU. 2004.

Hedija, V., Fiala, R. 2019. Is Gibrat's law valid for travel agencies and tour operators? Evidence from the Visegrad group countries. Journal of East European Management Studies, 2019, vol. 24, issue 3, 447-465, https://doi.org/10.5771/0949-6181-2019-3-447

Horváth A Partners, 2004. Nová koncepce controllingu. Praha: Profess Consulting s.r.o.

Konečný, M.2007. Controlling: studijní text pro kombinovanou formu studia. Brno: Akademické nakladatelství CERM.

Mann, R., 1992. Controlling - Metóda prosperujícího podnikání. Praha: Profit, a. s.

Mikovcová, H. 2007. Controlling v praxi. Plzeň: Aleš Čeněk.

Sládek, G., Valentová, K., 2006. Controlling hotela a reštaurácie. Bratislava: Iura Edition.

Onuferová, E., Čabinová, V. 2018. Enterprise Performance Analysis of the Selected Service Sector by Applying Modern Methods with an Emphasis on the Creation and Application of the Modified Creditworthy Model (MCWM). Journal of tourism and services. 9 (17). pp. 97-122. doi:10.29036/jots.v9i17.74

Steinöcker, R., 1992. Strategický controlling. Praha: BaBtext.

Synek, M. a kol., 2003. Manažerská ekonomika - 3. přepracované a aktualizované vydání. Praha: Grada.

Synek, M. a kol., 1996. Manažerská ekonomika. Praha: Grada Publishing.

Šenková, A., Luchavová, R. 2018: Implementácia metódy balanced scorecard v kúpel'nom podniku. Acta academica karviniensia. Vol.18, č. 4. - Karviná, (2018), p. 79-88.

Širá, E., Vavrek, R., Pukala, R. 2018: Risk management and financing among Start-ups. Risk management and financing among Start-ups. Vol. č. 4. - Sumy, (2018), p. 153-161.

Tej, J., Ali Taha, V. 2017. Základy manažmentu rizík. Prešov: Bookman, 2017. 85 p.

Vidová, Helena, 2009. Logistický controlling. Bratislava: Nakladatel'stvo STU.

Vollmuth, H., 2001. Controlling nový nástroj ř́zení. Praha: Profess Consulting s.r.o.

Vollmuth, H., 2004. Nástroje controllingu od A do Z, Praha: Profess Consulting s.r.o.

Vravec, J. 2012. Vybrané kapitoly z podnikového controllingu. Prešov: Bookman s.r.o 